\title{
Evaluating scour at marine gravity foundations
}

Richard J. S. Whitehouse BSC(Hons), PhD, C.Geog, FRGS Technical Director, HR Wallingford, Wallingford, Oxon, UK James Sutherland BSC, PhD, C.Phys

Principal Scientist, HR Wallingford, Wallingford, Oxon, UK
John M. Harris MSc (Eng), PhD, CEng, CMarEng, CMarSci, FIMarEst, MASCE

Principal Engineer, HR Wallingford, Wallingford, Oxon, UK

This paper analyses scour at offshore foundations, with special reference to gravity base foundations which are used in a range of applications including oil and gas production, wind farm foundations and subsea infrastructure protection, such as concrete covers to pipelines. Two published empirical methods available for evaluating scour are reviewed and compared with laboratory and field data. The methods that are presented are reasonable for first-order assessment although they do not represent the inclusion of skirts. In a vigorous scour environment the foundation is liable to be undermined and scour protection will be required. A flow chart for a scour management plan is proposed to integrate scour considerations into the life cycle management of the gravity base foundations and some improvements that can be made to the predictive capabilities are outlined.

\section{Notation}

\section{$D$}

$D_{\mathrm{c}}$

$D_{\mathrm{p}}$

$g$

h

$h_{\mathrm{c}}$

$h_{\mathrm{s}}$

K

L

N

$S$

$S_{\text {max }}$

$U$

$U_{\text {cr }}$

$\alpha_{\mathrm{c}}$

\section{Introduction}

Marine gravity base foundations (GBFs) rely on their own weight to keep them stable on the seabed, with pin piles or skirts to provide additional lateral resistance. Two types are often defined, namely gravity base structures (GBS) fabricated from steel - or concrete gravity structures (CGS). They are of various heights, shapes, sizes and composite forms depending on their function. GBFs are used in oil and gas projects, for platforms (Dahlberg, 1983), for subsea installations such as manifolds, for providing protection against trawl board or anchor impact (Whitehouse et al., 2010), and for wind farm foundations (Byrne and Houlsby, 2003; Thomsen et al., 2007; Zaaijer, 2003). The use of concrete caissons is also common in maritime civil engineering projects for bridge, breakwater and harbour construction (CIRIA, 2010; Hawkswood and Allsop, 2009). A recent overview of some proposed concrete GBF solutions for offshore wind has been prepared by The Concrete Centre (2010). For GBFs, both large and small, the scour response will vary spatially around the structure, particularly at corners and along edges.

The impact of foundation scour on appurtenances, $\mathbf{J}$ or I tubes and the associated power cables and umbilicals, and pipelines in the case of oil and gas foundations, is not included in the current paper and will need to be considered in light of the specific geometry of the features, depth and extent of scour and the disturbed flow regime near to the GBF.

Effective foundation engineering requires the combined understanding from structural, geotechnical and hydraulic-sediment transport disciplines to provide an evidence-based approach to delivering a stable and scour-resistant foundation. The key considerations for foundation performance are covered by published standards with respect to the limit states for safety against sliding and bearing capacity failure. Analysis of the challenges presented by small GBFs (Fisher and Cathie, 2002) provides a useful checklist of the steps in the design process.

Loss of soil contact can occur due to scour, piping, and potentially liquefaction, both due to rocking of the base and directly through wave-induced cyclic loading of the soil by 
waves or seismic activity, although this can be mitigated with skirts and drainage systems under the foundation. Bed preparation is often employed to improve foundation conditions by removing the effect of an uneven seabed and providing a drainage layer to prevent build-up of excess pore pressures.

This paper considers aspects of the scour process for GBFs as used in a range of marine applications and illustrates aspects of the scour development as well as the consequences for foundation design.

\section{Scour management plan}

The adoption of a scour management plan (SMP) provides a framework for considering scour interaction during the GBF project life cycle (Figure 1). The expected scour levels are assessed through scour hazard assessment, predictions using available formulae and laboratory-scale modelling. Evidence from existing structures or analogues in the field may also provide useful information. An important factor, not discussed in this paper, is the variation in bed levels due to bedform movement and general bed change; both of these will need to be included in the scour assessment as they influence the overall bed level. The data available at different stages of a project are summarised in Table 1 and it is clear that the level of detailed information usually increases through the project life cycle, adding more certainty to the understanding of bed level change and scouring. The framework should also be used to cover decommissioning of structures at the end of their life.

The management of scour through monitoring against predefined bed level criteria provides a risk-based approach to identifying whether remedial or mitigation measures are required (Figure 1). Monitoring at regular intervals allows the location, depth and extent of scouring to be determined and compared with the design assumptions. Routine surveys for scour can be used to establish the progressive nature of scour development at scour critical sites, or confirm low scour where that has been predicted. The use of datum points or horizontal reference lines on the side of the foundation allows visual monitoring of bed levels with remotely operated vehicles (ROVs) or by divers following installation. Alternatively, graded scour poles installed in the seabed can be used (Dahlberg, 1983). For comparison with predicted scour it is valuable to obtain information during periods of calm weather, when tidal currents pick up and generate most of the scour, and to compare immediately post storm to see how much variation occurs; although this may not detect the peak scour depth as infill will already have occurred.

An innovative approach to the management of scour was taken in the Thornton Bank project (Bolle et al., 2009). This is because the GBF solution was pre-dredged by $3.5 \mathrm{~m}$ and hence was unusual compared with the majority of support structures for currently constructed offshore wind farms. To manage risk the scour of the backfill around the foundations was monitored with multibeam echo sounding equipment over a 2-month period in summer 2008, and the same procedure was adopted following placement of the filter layer on top of the backfill. In this case the bed levels were monitored for a period of 1 to 2.5 months in late summer and early winter of the same year prior to placement of the rock armour. In all cases the monitoring was compared against three preset target levels - alarm level, intervention line and danger line. These levels provided an objective framework for management of the seabed profile around the foundations and determining whether remedial work was required.

As well as multibeam echo sounders, rotating head scanning sonars have been used for detailed structure-seabed monitoring. The present authors have proposed the use of this technology on offshore structures in combination with metocean time-series measurements to provide three-dimensional data on scour evolution. Continuous monitoring of scour using simple and cost-effective real-time scour monitors would also provide a means for evaluating scour during storm periods. This approach has been used for management of scour at rail bridges and road bridges (CIRIA, 2002) and has been used to show scour variations at seawalls (Sutherland et al., 2006). The authors would be interested to hear about cases of real-time scour monitoring of offshore structures.

Evidence for scour response from Round 1 and other built windfarms has been published by Whitehouse et al. (2011). This work was based on scour surveys obtained primarily for the purpose of environmental monitoring. A new phase of Round 2 and Round 3 developments in offshore wind will see new foundations being installed at an unprecedented rate. Monitoring even a small number of different foundations in contrasting environments would provide the additional evidence for scour evolution and variability that is currently lacking in guidance. Investment in monitoring technology will be required to deliver the data that are required for improved prediction and scour management.

\section{Scour processes}

There are a number of approaches that can be taken with respect to scour analysis (Whitehouse, 1998). The current paper concentrates on the existing empirical methods and information from laboratory and field cases. The seabed soil response at a specific site is controlled by the flow around the structure and through the seabed. Flow acceleration and turbulence generation around the structure gives rise to locally enhanced transport of sediment, and the creation of local gradients in the sediment transport rate which lead to local erosion of the seabed around the structure (i.e. scour) (Sumer and Fredsøe, 2002; Whitehouse, 1998). Where scour takes 


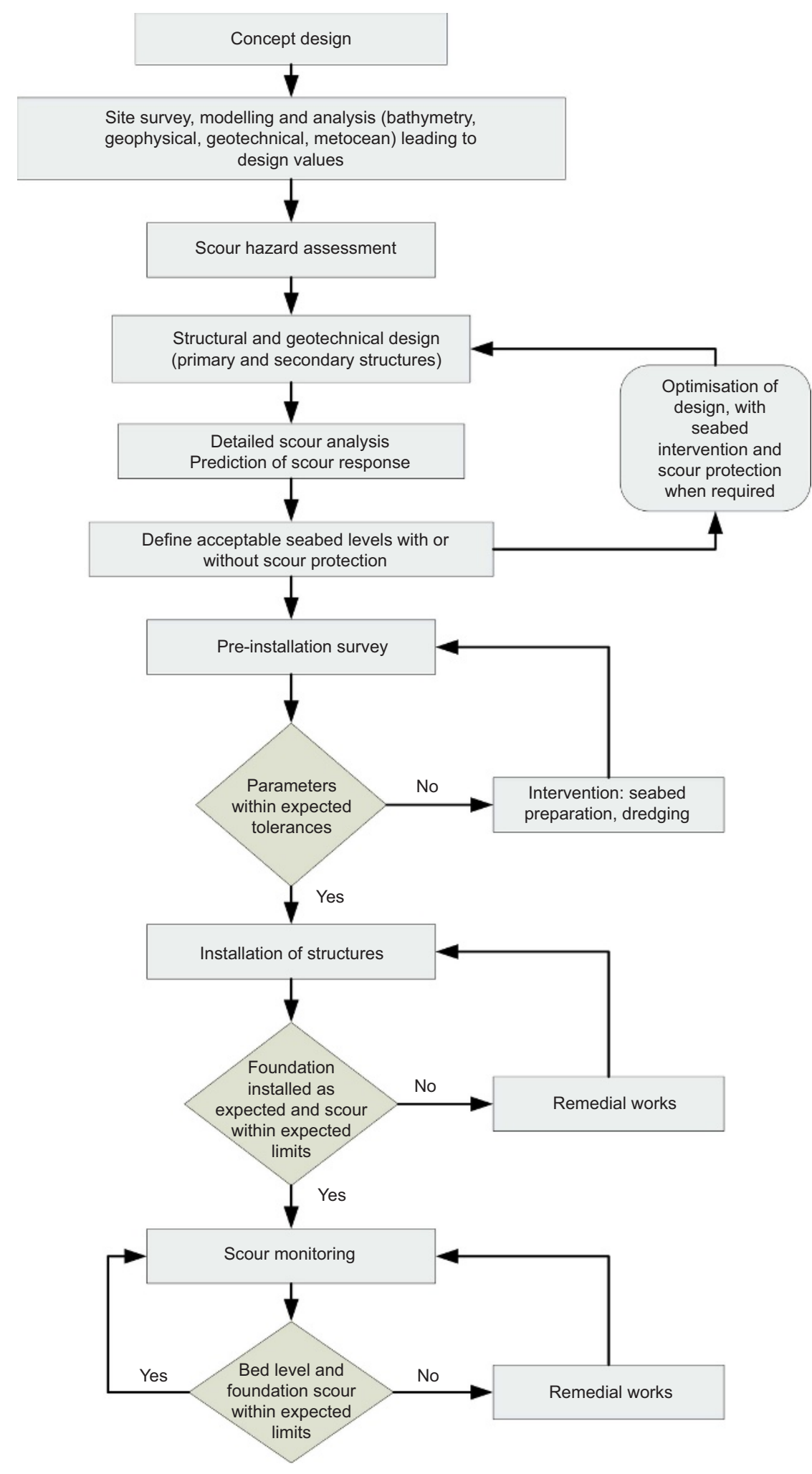

Figure 1. Scour management plan flow chart 


\begin{tabular}{lll} 
Stage & Activities & Data \\
\hline Concept design & Feasibility & Chart \\
& Option selection & Published data \\
& Functional requirements & \\
Design & Pre-FEED & Site survey \\
& FED $^{\mathrm{a}}$ & Monitoring \\
& EPC $^{\mathrm{b}}$ & Modelling \\
& Verification & \\
Installation & Site preparation & Engineering surveys \\
& Installation & Diver/ROV' surveys \\
Operation & Structural monitoring & Monitoring surveys \\
& Scour monitoring & Diver/ROV surveys \\
& Scour protection monitoring & \\
\end{tabular}

${ }^{a} F E E D$, front end engineering design; ${ }^{b} E P C$, engineer, procure, construct; ${ }^{c} R O V$, remotely operated vehicle

Table 1. Levels of information typically available to inform the

scour management plan

place in sand or gravel the material is likely to generate local deposits associated with that scour, whereas if the scour occurs on silty or clay seabeds the eroded material is likely to be carried away from the site in suspension, leaving a depression which may not readily be infilled by natural processes. The scour response is progressive with tidal currents and may develop more quickly under storm conditions, especially when tidal currents are enhanced.

When the magnitude and/or the duration of currents or storminduced currents are insufficient to achieve the characteristic time-scale required for scour to develop, the scour will not reach its equilibrium depth. Conversely, the scour caused by the oscillatory motion of waves is less extensive and takes a shorter time to develop to its equilibrium depth. Currents (tidal or steady) promote scour, and wave action from different sectors and of varying magnitudes will enhance the rate of scour development, but can reduce the equilibrium depth. Measurements of the backfilling of a simulated equilibrium current-induced scour hole around a monopile by waves has been carried out in a large wave flume (Sørensen et al., 2011). This illustrates that the pattern and depth of scour associated with stationary combinations of waves and currents may not be achieved. For a monopile foundation sited in a mixed wave and current environment, an analysis of the temporal variations in scour that can occur has been presented by Harris et al. (2010a). Predictions of the scour evolution under time-varying metocean conditions provide a basis for an exceedance curve for scour, in hindcast or forecast mode, which can be used as input to a risk-based assessment of scouring in the scour management plan.

\section{Some experience with gravity base foundations}

As stated earlier, GBFs are of varying shapes and sizes with a flat or ribbed underside and may have dowels, mudmats and/or skirts. Effective foundation solutions must be installable with respect to float-out and ballasting down onto the seafloor, or lowering from floating crane barges or jack-ups.

Dahlberg (1983) reported on scour at the Frigg TP1 GBF in the North Sea in $104 \mathrm{~m}$ water depth. The concrete cellular caisson foundation design was $72 \mathrm{~m}$ square and $44 \mathrm{~m}$ high with two $12 \mathrm{~m}$ columns supporting the topsides. The flat base had a number of precast concrete skirts penetrating $2 \mathrm{~m}$ into the seabed (Burland et al., 1978). The uppermost layers of seabed soil comprised fine sand in the range $0 \cdot 1-0 \cdot 2 \mathrm{~mm}$ and had low resistance to scour. Observations from this foundation revealed scour at two corners of about $2 \mathrm{~m}$ depth, which had developed mainly during the summer months. Remedial measures using gravel bags and gravel fill proved effective to remove further scour problems. The sensitivity of scour to foundation shape was highlighted by comparison with the nearby TCP2 structure in $102 \mathrm{~m}$ of water with $4 \mathrm{~m}$ of dense sand overlying clay; TCP2 had a 'more or less circular base' (Dahlberg, 1983: op. cit., p. 618). This foundation was only $40-50 \mathrm{~m}$ away from TP1 (Dahlberg, 1983; Kjekstad and Stub, 1978) and yet no scour was experienced in the surficial fine sand. Elsewhere in the North Sea, platforms placed directly on clay, and without scour protection, had not experienced scour at the time the paper by Hoeg (1991) was published. The authors are not aware of a similar paper published more recently, although anecdotal evidence from offshore industry contacts has 
indicated no significant scour problems with clay sites. More documentary evidence is required to confirm this.

In shallower water of $30-50 \mathrm{~m}$ in the North Sea the scour environment in sand is more vigorous. The scour around a rectangular GBF $(75 \mathrm{~m}$ by $80 \mathrm{~m}$ by $16 \mathrm{~m}$ high in $42.3 \mathrm{~m}$ of water) was measured in the field as $2.5-3.5 \mathrm{~m}$ in $0.15 \mathrm{~mm}$ sand (Bos et al., 2002). The use of a skirted foundation provides some protection against scour undermining the base (underscour) but does not prevent scour from occurring. Tests in a wave-current facility (1:40 scale tests of Whitehouse, 2004) with a simulated $19 \mathrm{~m}$ diameter circular deep skirted caisson showed that in a vigorous scour environment dominated by currents the skirt can promote the continuing development of scour - when the scour development is not limited by the duration of the scouring event and the sand layer is unlimited. In areas with limited scour development arising from low mobility due to currents, or wave-dominated conditions, the scour depth is reduced and the presence of a skirt may adequately protect against underscour.

In offshore wind farm guidance, GL (2005) states that, because GBFs rely on compressive contact with the supporting soil, designers will take measures to 'prevent scouring and wash-out phenomena, e.g. with the help of scour skirts, concrete mats, rock riprap or other suitable means' (Section 6.7.9.5 (1)). GL also states that 'a certain level of inevitable scouring has to be taken into account in the basic design assumptions'. DNV (2007) states that GBFs will 'for all locations require some form of scour protection, the extent of which is to be determined during detailed design' (Clause F201). As well as the specific mention in GL (2005) of some structures having 'scour skirts', from the historical perspective of offshore structures Stubbs (1975: p. 74) stated 'A vertical skirt is the most efficient means of providing scour protection provided the depth of the sand stratum is not excessive'. Therefore, it is essential to know the likely development of scour as one of the inputs to foundation and skirt design.

\section{Seabed preparation and installation}

O'Riordan and Clare (1990) observed that existing offshore design codes concentrated on the in-service performance and concluded that installation activities must not invalidate the design assumptions for the in-service conditions. They provided a methodology for scour assessment for a large rectangular GBF, stating that scour should be considered in the installation phase including both

(a) scour during initial touchdown

(b) scour on completion of installation.

For GBFs, including those with skirts, scour during installation can be reduced by making the final bed approach and initial skirt penetration during the slower of the two half-tides (flood or ebb) with an asymmetric tidal current, at slack water, or during a period of neap tides. These considerations are borne out by direct experience in shallow water of the complete development of scour holes during a spring tide cycle, albeit around a large monopile foundation, compared with the slow development during neap tide conditions (Ottesen-Hansen, 2005). Installation during low wave activity will be beneficial as it will reduce the vertical motion and pumping of water between the foundation and the seabed. Once the skirt has penetrated the bed the relative rates of scour depth development and penetration speed of the skirt tip should be considered, especially in sand. The following locations are usually the most vulnerable for scour (O'Riordan and Clare, 1990)

(a) the corners of the GBF (assuming a non-cylindrical shape)

(b) the leading skirt edge - especially in the final phases of touchdown

(c) around templates and pipelines outside the foundation.

Installation of foundations achieved with anchored moorings or tug assistance can be validated in laboratory tests. Installations in deep and fast flow, such as the concrete caissons used for the Tacoma Narrows second bridge crossing (49 $\mathrm{m}$ of water), required complex anchoring. The layout and performance was optimised with physical model tests to assess operational stability (Chakrabarti and McBride, 2005). The considerations in that work were very similar to those raised by O'Riordan and Clare (1990) and, in the Tacoma Narrows case, included the determination of a stable bed layer (bed preparation) to prevent scour in the closing stages of installation.

The in-service situation is covered by a detailed scour assessment and where scour protection is required the filter and rock armour layer scour design can be evaluated in laboratory tests. Tests were published by Hebsgaard et al. (1993) for the Øresund Bridge (water depths up to around $30 \mathrm{~m}$ ) with $17 \mathrm{~m}$ by $30 \mathrm{~m}$ rectangular caissons up to $9 \mathrm{~m}$ high. Post-installation experience at one of the piers revealed the action of storm-induced currents and waves undermined the pier shortly after installation such that 'it required an extensive grouting program to fill under the base' (Gerwick, 2000). A filter course of stone was then placed around the pier and covered with heavy riprap following the laboratory tested design of scour protection.

The early days of offshore wind energy using GBFs in shallow water, and more recent experience in deeper water, has pushed the limits for these foundations (Thomsen et al., 2007). Although large GBFs are used in deep water oil and gas developments the economics in offshore wind energy and need 
for large numbers of foundations in deeper water may preclude the use of gravity structures in favour of piled steel jackets, suction caisson foundations or floating structures. That is why work on concept studies for GBFs has been carried out to explore different approaches to achieving cost-effective options (Brook Hart et al., 2010; The Concrete Centre, 2010). (The authors note floating structures will require anchoring to the seabed as a key facet of that solution.) The existing GBFfounded turbine structures used in five Danish offshore wind projects (1991-2007; Villalobos, 2009) are in shallow water depths of 3-9.5 m to mean sea level. For example, the Nysted Offshore Wind farm used a $15.5 \mathrm{~m}$ wide hexagonal-shaped foundation with ballast cells, filled with high-density fill (olivine). The soil conditions were generally stiff moraine clay providing high-bearing capacity (Krogh et al., 2011; Thomsen, et al., 2007). Despite this, some dredging and placement of a stone layer for the foundation was required, with scour protection also being installed. In the case of Thornton Bank, Belgian sector (Bolle et al., 2009; Peire et al., 2009) the difficulties of dredging and placing granular material on the seabed in $20-30 \mathrm{~m}$ of water during foundation installation were overcome, whereas in the early days of deep water oil and gas foundations the inherent limitations of survey methods meant that seabed preparation was not often possible and 'the structure must be able to accept the seabed as it exists' (Stubbs, 1975: p. 74). Modern methods of survey and the precision of dredging equipment means that seabed preparation can be specified and monitored with confidence for foundations placed in up to $30 \mathrm{~m}$ of water (dredging and backfill for the six Thornton Bank GBFs) and even in $43 \mathrm{~m}$ of water on an uneven seabed $(120 \mathrm{~m}$ by $95 \mathrm{~m}$ coverage with $20 \mathrm{~mm}$ graded rock dump mounds for the Malampaya GBF; McNulty et al., 2002).

In areas where seabed preparation is required, and feasible under the technical and economic constraints of the project, it may be possible to combine the functionality of bed preparation material with a scour preventative function under the expected loadings provided it does not impede the penetration of the skirt when fitted. In areas with currents sufficiently high to cause erosion of the bed it is recommended that scour protection vessels should be on station to place material at the most vulnerable locations should this become an issue during installation. Guidance for offshore wind turbines DNV (2007) and GL (2005) both recognise the importance of the installation phase in the project cycle.

\section{Predicting scour depth}

The scour hazard assessment element (Whitehouse, 2006) of an SMP (Figure 1) involves calculating the stability of the seabed soil to scouring, namely whether scouring is likely to be of concern. If scour is identified as an issue, the next step is to predict the depth of scour that could occur. The dimensions of the foundation exert the major controlling influence on the scour depth $S$, and hence it is conventional to non-dimensionalise $S$ with the characteristic length-scale of the foundation. For piles of all sizes the pile diameter $D_{\mathrm{p}}$ is the relevant parameter. Slender piles have a pile diameter to water depth ratio less than 0.5 (Whitehouse, 1998), and for non-slender piles it is usually assumed that a reduction in relative scour depth (i.e. $S / D_{\mathrm{p}}$ ) occurs when the water depth falls below three to five times the pile diameter (Whitehouse, 1998). The height of the pile (with respect to the total water depth) is also important as shorter piles present less disturbance to the flow and less scour than a higher pile of the same diameter (Simons et al., 2009; Sumer and Fredsøe, 2002; Whitehouse, 1998). For GBFs scour is related to the diameter or length of side of the foundation, $D_{\mathrm{c}}$, and the height of the foundation above the seabed level, $h_{\mathrm{c}}$. The shape of the foundation also plays a role in determining scour and is taken into account for caisson and pile calculations. The current paper concentrates on evaluating just two of the predictors which are considered to be relevant to GBF scour prediction. A much wider range of methods for scour prediction around marine structures are covered in detail by Hoffmans and Verheij (1997), Whitehouse (1998) and Sumer and Fredsøe (2002).

For predictions, in this case of jack-up spudcans, Rudolph et al. (2005) summarised a number of field observations and laboratory tests and concluded the maximum scour depth in a mobile seabed location $S_{\max }$ was related to the height of the spudcan, $h_{\mathrm{c}}$, above seabed level after initial penetration. They proposed a simple formula based on the height of the foundation with which to make a first-order estimation of the maximum scour depth

1. $S_{\max }=K h_{\mathrm{c}}$

They suggested the value of the dimensionless coefficient $K$ was in the region 0.2 to 2 . They noted the values of $K$ did not necessarily correspond to the equilibrium scour condition, which may be one of the reasons for such a wide variation in $K$, and that for a 'proper scour assessment, a careful analysis of the site conditions and spudcan characteristics is required' (Rudolph et al., 2005; p. 295). This is inherent in the general scour hazard approach (Figure 1). Equation 1 will be used to give comparative values of $K$ for other structures.

Hoffmans and Verheij (1997) presented the Khalfin (1983) current-only scour predictor for a GBF with the following modified features.

(a) The pile diameter was replaced by a characteristic length, $D_{\text {c }}$, taken as the average of the length and breadth of the GBF. 
(b) The flow depth, $h$, in the water depth to diameter ratio $h /$ $D_{\mathrm{c}}$ was replaced by the GBF height, $h_{\mathrm{c}}$.

(c) The undisturbed depth-averaged flow velocity was multiplied by $\alpha_{c} / 2$ with $\alpha_{c}=2$ for a circular structure, and $\alpha_{c}=2 \cdot 3$ for a rectangular GBF expressing the additional turbulence generated at the corners of the structure. The coefficient $\alpha_{c}$ is an influence factor that represents the flow enhancement near the structure caused by the structure.

The equation for scour depth, $S$, is given as Equation 2

2.

$$
\begin{aligned}
& \frac{S}{D_{\mathrm{c}}}=8.96\left(2 \frac{0 \cdot 5 \alpha_{\mathrm{c}} U}{U_{\mathrm{cr}}}-1\right)\left(\frac{h_{\mathrm{c}}}{D_{\mathrm{c}}}\right)^{1 \cdot 43}\left[\frac{\left(0 \cdot 5 \alpha_{\mathrm{c}} U\right)^{2}}{g h}\right]^{N} \\
& \text { with } U / U_{\mathrm{cr}}=1 \text { for } U \geq U_{\mathrm{cr}} \text { and } N=0.83\left(\frac{h_{\mathrm{c}}}{D_{\mathrm{c}}}\right)^{0.34}
\end{aligned}
$$

Here $U_{\text {cr }}$ is the value of depth-averaged flow velocity for initiation of sediment motion $(\mathrm{m} / \mathrm{s})$ and $g$ is gravitational acceleration $\left(\mathrm{m} / \mathrm{s}^{2}\right)$. Given that the Froude number, $U /(g h)^{0 \cdot 5}$, in the marine environment is generally $<<1$ this provides a practical limit for the last term in Equation 2. The experimental data used by Khalfin was in the range $0 \cdot 01-0 \cdot 10$. The predictions from these equations are evaluated in the next section for a range of GBF geometries and sizes. The original Khalfin expression was based on experiments with grain size in the range $0 \cdot 12-3.0 \mathrm{~mm}$, cylinder diameter $0.05-1.0 \mathrm{~m}$, water depth $0.05-0.98 \mathrm{~m}$ and current speed $0.15-0.66 \mathrm{~m} / \mathrm{s}$.

\section{Evaluation of scour depth predictors}

A range of experimental and field data have been used to evaluate the prediction of scour depth.

Whitehouse (2004) showed time-series of sand bed scour development data with Froude-scaled time (Whitehouse, 1998) at a monopile and a girder top caisson, to which has been added data from a full-depth caisson (Table 2 and Figure 2). The scour depth for the full-depth caisson at the end of the test run was deeper than the other two test cases. It equated to $0 \cdot 37 D_{\mathrm{c}}$, compared with $0 \cdot 18 D_{\mathrm{c}}$ for the girder top caisson, and $0 \cdot 94 D_{\mathrm{p}}$ for the monopile. The result demonstrates the importance of the size of the foundation and height above the bed on the absolute scour depth, as well as on the rate of scour. Comparison with Equation 1 for the girder top caisson (Test 3, Table 2) suggests a value of $K=1.75$ based on the initial height of the foundation above the seabed $\left(h_{\mathrm{c}}=2 \mathrm{~m}\right)$. This is within the range for $K$ quoted by Rudolph et al. (2005). The value of $S$ calculated with Equation 2 for Test 3, using the prototype scale values and assuming live-bed conditions, is $1.82 \mathrm{~m}$ which is less than the measured value. This is most likely because of the effect of the deep skirt which is represented in Equation 2 only by the initial value for height of caisson of $2 \mathrm{~m}$. As the scour progresses, the effective value of $h_{\mathrm{c}}$ increases and hence so does the scour depth. A calculation of the scour depth for $h_{c}=h$ in Equation 2 has been made for the conditions of Test 11 (Table 2) and a close agreement was found with the predicted value being $7 \mathrm{~m}$. However, it is noted that the scour depth measured in Test 11 may not have been the final value.

Equation 2 was evaluated for the range of structure dimensions and water depths listed in Table 3 and the results have been plotted in Figure 3. The main controlling factors on the lines are the value of flow speed which determines the onset of scour (i.e. the velocity with predicted scour depth equals zero) and the value at which velocity equals the threshold of sediment motion which governs the transition point between the curved and straight line sections of the predicted scour.

Application of the predictor to a structure similar in size to the one evaluated by Bos et al. (2002) gives the 'S North Sea GBF' curve in Figure 3, which indicates that the method tends to overpredict, as the predictions $(3 \cdot 5-4 \cdot 6 \mathrm{~m})$ over the characteristic range of velocities are larger than the observed scour of $2 \cdot 5-3 \cdot 5 \mathrm{~m}$. As the range of observed and measured scour overlap for the smallest velocity and largest measured scour, the predictions are considered to provide a conservative value for this type of structure.

For the 'Cover GBF' (Whitehouse et al., 2010), scour at the site commenced within a month of installation, leading to some undermining of the footings of the cover, and within 4 months observations showed scour-induced settlement had taken place. The scour led to an overall settlement of the structure by about $1.25 \mathrm{~m}$ which is of a reasonable order in comparison with the scour prediction in the characteristic range of velocity.

For the 'Small GBF', field observations with a fine sand in deep water show that for a current speed of $1 \mathrm{~m} / \mathrm{s}$ (the design current) an associated prediction of around the same order as that observed $(0 \cdot 3 \mathrm{~m})$ is achieved, with the skirt tip becoming exposed (Figure 4). Given that the gradient of the prediction curve is very low, the value of $\alpha_{c}$ (Table 3 ) could have been increased to about $2 \cdot 6$ to provide a better prediction.

Predictions for a large terminal 'Full-depth GBF' (see Chen et al., 2011) have been included in Figure 3, which indicate very large scour depths in unlimited sand thickness, even for low flow speeds. Therefore, although there are currently no field data published to verify this prediction, it may be that this is overly simplistic for a large structure and provides a conservative prediction for the marine environment as the scour will be spatially variable around the perimeter of the 
Test number
Maximum scour depth after $10 \mathrm{~h}$ $3 \cdot 4 \mathrm{~m}$ $1 \cdot 5 \mathrm{~m}$ $5 \cdot 5 \mathrm{~m}$
Maximum scour depth at end of test

$4 \cdot 3 \mathrm{~m}$ at $36 \cdot 1 \mathrm{~h}$

$3.5 \mathrm{~m}$ at $28.6 \mathrm{~h}$

$7 \cdot 0 \mathrm{~m}$ at $19 \cdot 5 \mathrm{~h}$
Monopile: $D_{\mathrm{p}}=4.6 \mathrm{~m}$

Girder top caisson: $D_{\mathrm{c}}=19 \mathrm{~m}, h_{\mathrm{c}}=2 \mathrm{~m}$, $D_{\mathrm{p}}=4.6 \mathrm{~m}$

$D_{c}=19 \mathrm{~m}$

Table 2. Summary comparison of measured scour depths in a current (1:40 scale tests with equivalent full-scale parameters of $10 \mathrm{~m}$ water depth, mobile fine sand, current of around $1.7 \mathrm{~m} / \mathrm{s}$ )

structure. For large structures like this the predicted scour of $5 \mathrm{~m}$ with a speed of $0.6 \mathrm{~m} / \mathrm{s}$ is only $0 \cdot 04 D_{\mathrm{c}}$ (scaled to the dimension in Table 3). Inclusion of a flow-depth-limiting term based on the hydraulics of the free surface flow interaction with the structure may be helpful. In spite of this it is noted that the prediction from Equation 2 compared with the current scour laboratory result for the surface-piercing caisson in Figure 2 gave a close agreement. Moreover, for a large structure such as this, once scour has undermined the skirt this would tend to relax the development of scour locally. Specific issues relating to this GBF are discussed later in this paper, drawing on the work of Chen et al. (2011).

A deterministic approach to scour prediction is normally used with a steady current and/or wave condition: in reality the water level, flow speed and direction all vary with time, influencing scour development as well as the associated variations of wave height, period and direction. Thus, the scour depth varies with time and the scour pattern fluctuates around the foundation. Predictions of scour depth have been made for full-depth caissons in tidal flow by May and Escarameia (2002) and recently for combined action of waves and currents at monopile foundations by Harris et al. (2010a). A time-varying method for GBF scour will help with understanding the scour variation.

\section{Layered soils}

A further complexity arises from the need to evaluate scour in clay, or in layered soils, for example, with sand overlying clay. The experience in Christchurch Bay of GBF towers installed in $9 \mathrm{~m}$ water depth is relevant (Bishop, 1980; Burland et al., 1978). The first tower was sited on $3 \mathrm{~m}$ of fine sand overlying clay. The central monopile column was $2.8 \mathrm{~m}$ in diameter on top of a $1.2 \mathrm{~m}$ high (estimated from Burland et al., 1978) and $10.5 \mathrm{~m}$ diameter concrete base weighing $200 \mathrm{t}$, with tapering flanks, and no skirt. The foundation experienced a settlement of $0.5 \mathrm{~m}$, and a scour depth which increased with time over about 2 months. Based on an average of measurements around

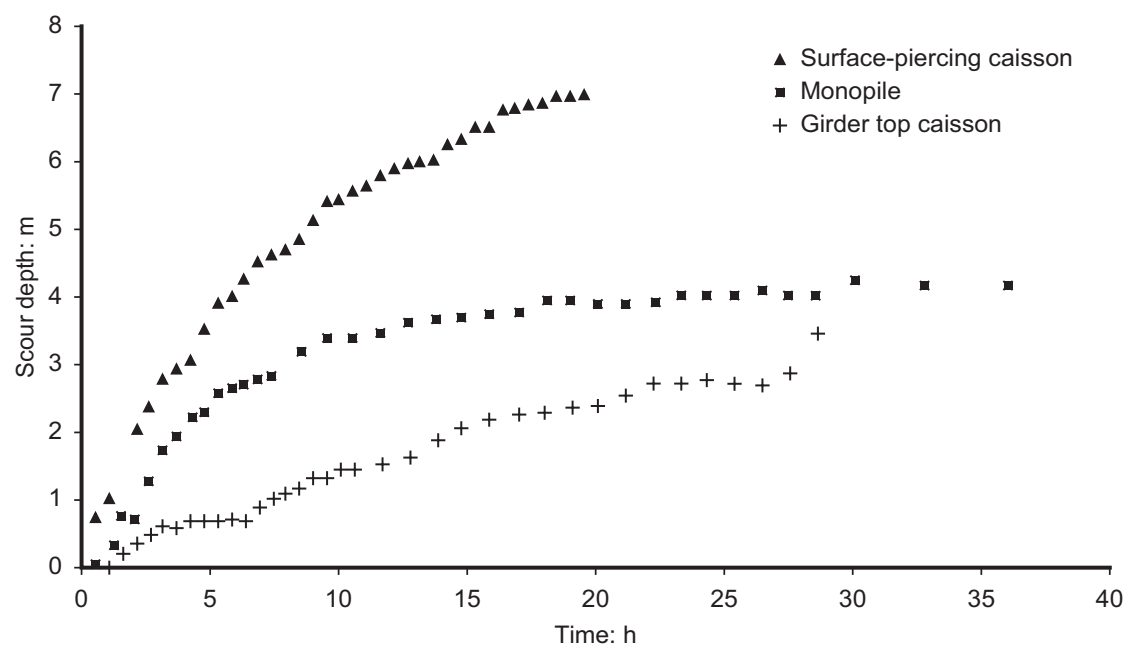

Figure 2. Comparison of laboratory test results for scour with three different structures in a steady current (structures in Table 2) 


\begin{tabular}{|c|c|c|c|c|c|c|}
\hline Case & $\begin{array}{c}\text { Average } \\
\text { dimension, } \\
D: m\end{array}$ & Height, $h_{\mathrm{c}}: \mathrm{m}$ & $\begin{array}{c}\text { Water depth, } \\
\quad h: \mathrm{m}\end{array}$ & $U_{\text {cr: }}: \mathrm{m} / \mathrm{s}$ & $\begin{array}{l}\text { Characteristic } \\
\text { range of } \\
\text { velocity: } \mathrm{m} / \mathrm{s}\end{array}$ & $\begin{array}{c}\text { Value of } \alpha_{c} \\
\text { used in } \\
\text { prediction }\end{array}$ \\
\hline Full-depth GBF (Chen et al., 2011) & 134 & $\begin{array}{l}\text { Same as } \\
\text { water depth }\end{array}$ & $30 \cdot 0$ & 0.5 & c. 0.6 & $2 \cdot 0^{\mathrm{a}}$ \\
\hline S North Sea GBF (Bos et al., 2002) & 75 & $16 \cdot 0$ & $42 \cdot 3$ & 0.5 & c. 0.6 to 0.8 & $2 \cdot 3$ \\
\hline Cover GBF (Whitehouse et al., 2010) & 16 & $3 \cdot 55$ & $30 \cdot 5$ & 0.5 & c. 0.8 to 1.0 & $2 \cdot 3$ \\
\hline Small GBF (Technip) & 6 & 0.6 & $100 \cdot 0$ & 0.6 & c. $1 \cdot 0$ & $2 \cdot 3$ \\
\hline
\end{tabular}

${ }^{a}$ Rounded corners to GBF.

Table 3. Input parameters for evaluation of scour predictor

Equation 2

the circumference, the scour increased from 0.5 to $0.7 \mathrm{~m}$; this was through the combined effect of hydraulic action and rocking of the tower foundation. The $K$ factor in Equation 1 would be around 0.4 for the initial scour and initial foundation height, and for the deepest average scour and a structure height reduced by $0.5 \mathrm{~m}$ of settlement the $K$ factor would be $1 \cdot 0$. These are within the range of the published values.

The foundation was removed and a second one with a $20 \mathrm{~m}$ diameter concrete base and weight of $800 \mathrm{t}$ was installed at another seabed location in Christchurch Bay with $0.5 \mathrm{~m}$ sand over clay. The foundation had sloping sides and an overall height of $1.5 \mathrm{~m}$ above the base (Bishop, 1980). It was fitted with a shallow skirt $0.7 \mathrm{~m}$ deep. Scour depths were measured by divers at eight locations around the foundation at four instances over about 2 years. Table 4 shows how many of the eight locations had scour depths $(a)$ in sand, $(b)$ in the clay within the limits of the skirt and $(c)$ in clay below the tip of the skirt. The results show scour of the clay took place as well as

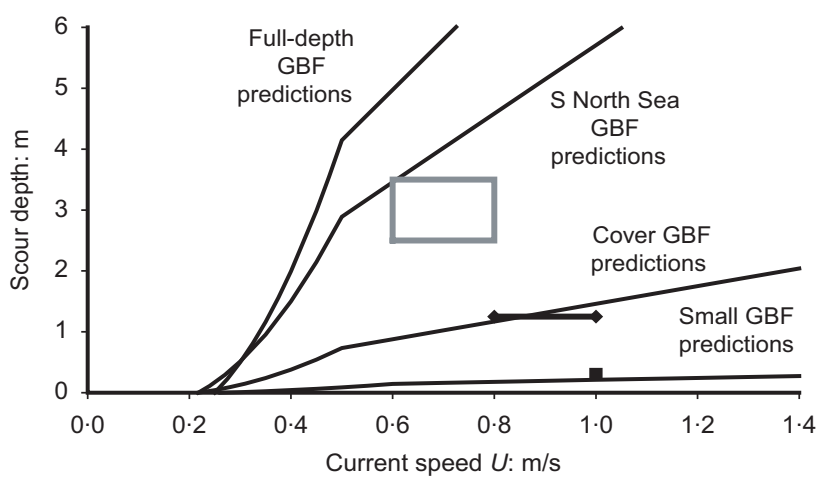

Figure 3. Observed and predicted scour for the range of typical structure geometries in Table 3: predictions from Equation 2, observed currents and scour for small GBF (square), cover GBF (diamond and horizontal line), S North Sea GBF (open rectangle) the overlying sand to a depth in excess of the skirt tip. In this case the $K$ factor in Equation 1 would be estimated at 0.53 , once again within the range of expected values.

Scour in a veneer of sand overlying clay or in layered soils needs to be evaluated on a case-by-case basis to determine the scour risk associated with the specific configuration of GBF, soil and hydraulic conditions. Such an approach for monopile foundations has been devised by Harris et al. (2010b). The large Adriatic LNG (liquefied natural gas) terminal GBF (Chen et al., 2011) was sited on $0.4 \mathrm{~m}$ of silty sand overlying clay and the steel skirt was $1 \mathrm{~m}$ long. Erosion rates for the exposed clay were estimated directly in laboratory tests on samples obtained from the field. The data provided direct evidence of the scour hazard and from analysis of the design storm conditions it was concluded that the skirt would be undermined and hence hydraulic tests were completed in the laboratory to optimise the scour protection.

\section{Composite structures and skirts}

Gravity base structures have different transition shapes from the foundation to the topsides which will exert a controlling influence on the flow field and the scour development pattern. The Department of Trade and Industry-funded scour tests investigated a range of these transitions simulating $10 \mathrm{~m}$ of water depth and fast currents with wave action. The structures included a flat-topped as well as a conical shape forming the transition between the $19 \mathrm{~m}$ diameter deep skirted foundation and the turbine tower (Whitehouse, 2004). The scour produced with the conical structure is shown in Figure 5(a). Compared with the flat-topped transition the overall scour for the conical shape was deeper for the same forcing conditions, as can be seen by comparing the depth contours of Figure 5(b) with Figure 5(a). A characteristic rate of scour curve for a flattopped foundation similar to the one in Figure 5(b) under current-only conditions was shown in Figure 2. The rate and final depth of scour was larger for the combined wave and 


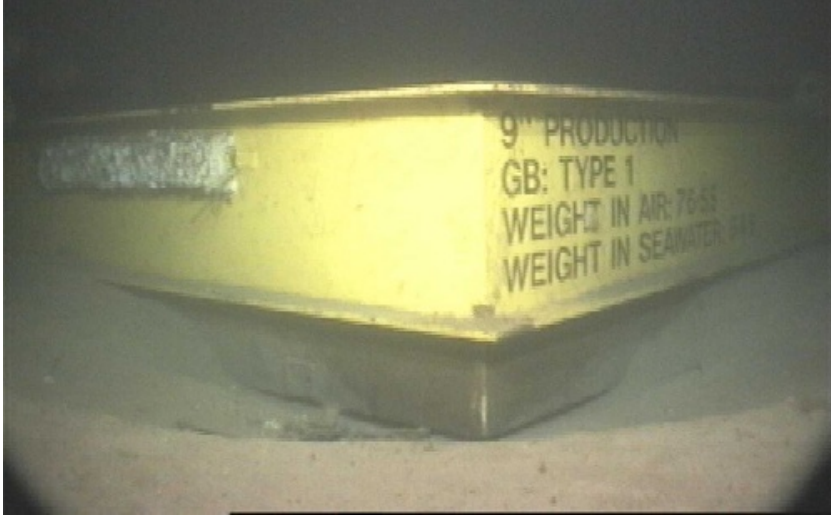

Figure 4. Small GBF in $100 \mathrm{~m}$ of water with scour and skirt exposure (photograph reproduced with permission from Technip Offshore UK)

current conditions, with the conical structure experiencing a rate that was 1.8 times faster (Whitehouse, 2004). The conical transition in Figure 5(a) has similarities to the GBF used recently on Thornton Bank for which scour test results were published by Bolle et al. (2009). The scour was less severe than that shown in Figure 5(a) as (a) the structure had a $23.5 \mathrm{~m}$ diameter flat-bottomed foundation (rather than a deep skirt) which had been placed about $3 \cdot 5 \mathrm{~m}$ below seabed level, $(b)$ the scour model simulated the placed filter material mobility rather than the natural seabed and (c) the water depth was greater. The scour around the foundation responds to the foundation shape in the water column near the seabed while higher up the structure provides additional flow blockage and the generation of vortices which will be advected by the current and may cause additional bed scour in the wake region.

Laboratory work by Yeow and Cheng (2004) with slender cylindrical structures studied the influence of the foundation detail for scour depth in wave action. They concluded that if a pile atop the caisson foundation was smaller than the caisson itself the scour depth around the foundation would be largely unaffected by the presence of the pile. This was because the foundation top absorbs some of the downflow from the pile. This was also found to be the case by Whitehouse (2004) simulating a $4.6 \mathrm{~m}$ diameter pile on top of a $19 \mathrm{~m}$ diameter

Scour categories determined from diver measurements at eight locations around foundation

Scour in sand $(0-0.5 \mathrm{~m})$

Scour in clay - above skirt tip $(0 \cdot 5-0 \cdot 7 \mathrm{~m})$

Scour in clay - under skirt tip $(>0.7 \mathrm{~m})$ foundation (Test 3 in Table 2, and Figure 2). Yeow and Cheng (2004) concluded that if the diameter of the upper pile is greater than $80 \%$ of the foundation diameter, the structure can be treated as a single vertical pile of the same diameter as the foundation, although the overall scour depth averaged about $75 \%$ of the value for a single pile under wave action.

The influence on the scour of the structure height and skirt depth are two key factors that require further investigation. The structure height is included in the predictors (Equations 1 and 2). Equation 1 (for spudcans) implicitly covers the case of a finite height structure with underside in contact with the seabed whereas Equation 2 reflects a foundation which extends down into the seabed rather than a flat-bottomed or skirted foundation. The roles of cylinder height and skirt depth were investigated in mobile bed laboratory tests by Simons et al. (2009). The results confirmed (as expected) that the scour depth in sand was reduced with lower structure height (Figure 6) from $1 \cdot 6 D$ to $1 \cdot 8 D$ with a full-depth structure $\left(h_{\mathrm{c}}=h\right.$ at $\left.h_{\mathrm{c}} / D=3 \cdot 2\right)$ to scour of $1 D$ and less for $h_{\mathrm{c}} / D$ less than $0 \cdot 5$. Despite the fact the structure was fixed so it could not settle, the scour did not extend below the bottom of the structure except for the shortest skirt length $(0 \cdot 48 D)$ for which the structure was undermined by scour; this is why the scour depth with $0.48 D$ skirt is reduced at $h_{\mathrm{c}} / D=3 \cdot 2$. The progressive reduction of scour with reduced skirt depth is clear for the smallest $h_{\mathrm{c}} / D$ test range and scattered for the middle range, due to experimental variation. When a bi-directional flow replaced a uni-directional flow (in the $1 \cdot 56 D$ skirt case at $h_{\mathrm{c}} / D=0 \cdot 36$ ) there was a marked reduction in the scour depth for the duration of the test. The limited duration of the test was not sufficient to determine whether the scour in the bi-directional flow case would have become as large as the steady flow, although this reduction in scour is consistent for the result for larger structures obtained by May and Escarameia (2002) who found the scour depth in tidal flow was smaller than steady flow.

Useful conclusions from the data are that scour triggered by the flow field around the portion of the structure above bed level initiates scour in the seabed, which exposes the previously buried portion or skirt and provides a positive feedback on the scour development. This behaviour was evident from tests with a $9.5 \mathrm{~m}$ buried skirted foundation of which the initial upstand of the foundation was just $2 \mathrm{~m}$ (Whitehouse, 2004). Based on the work

Table 4. Christchurch Bay tower scour results (Bishop, 1980) 


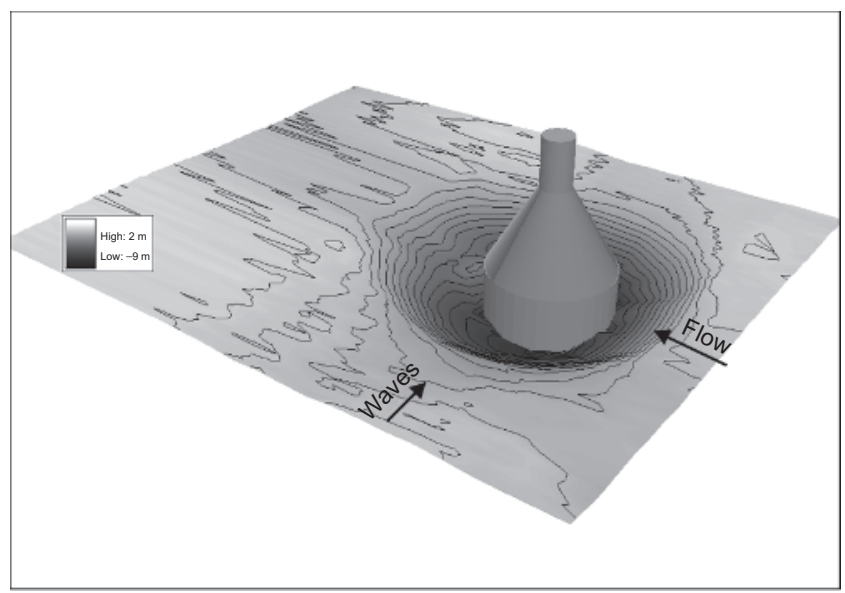

(a)

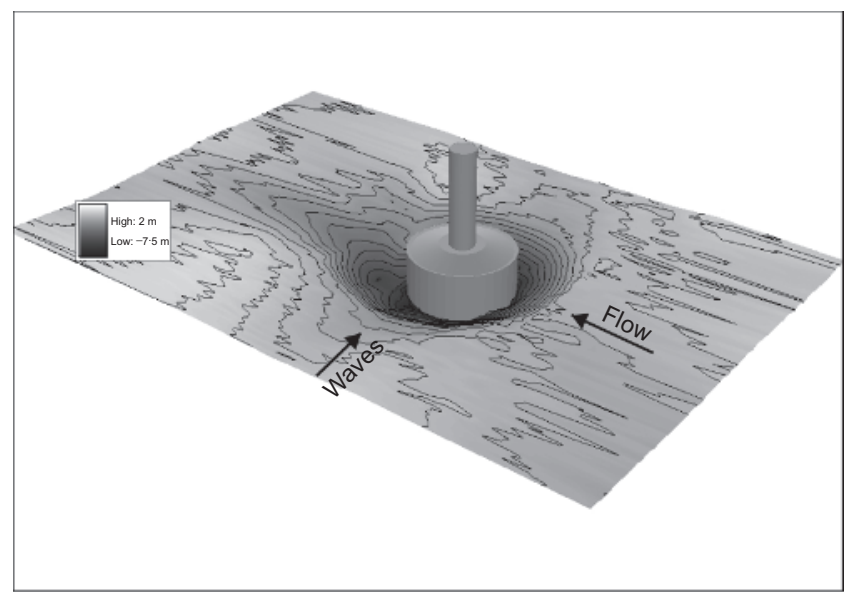

(b)

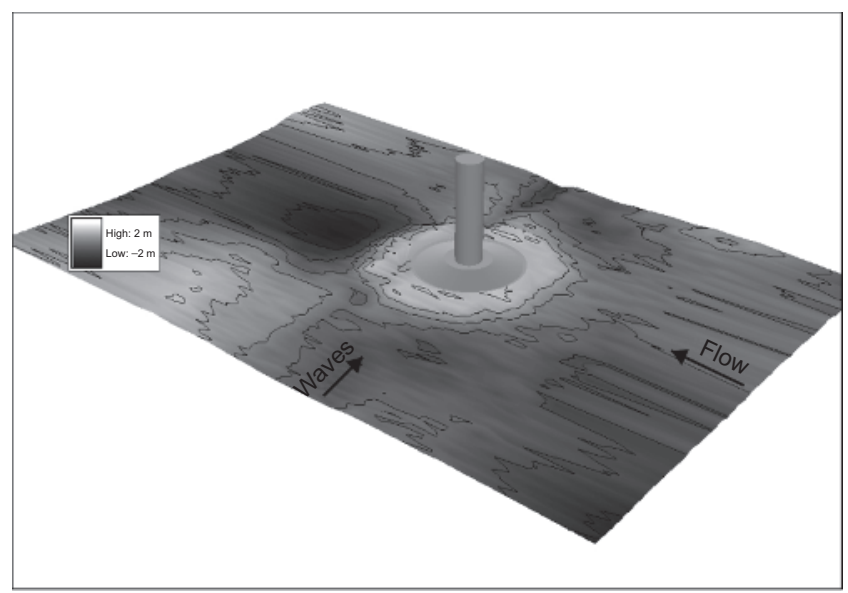

(c)

Figure 5. Scour test results from Whitehouse (2004) (plotted at field scale) with waves and currents: (a) conical transition between skirted foundation and tower section; (b) smooth concrete top transition; and (c) same as (b) with scour protection

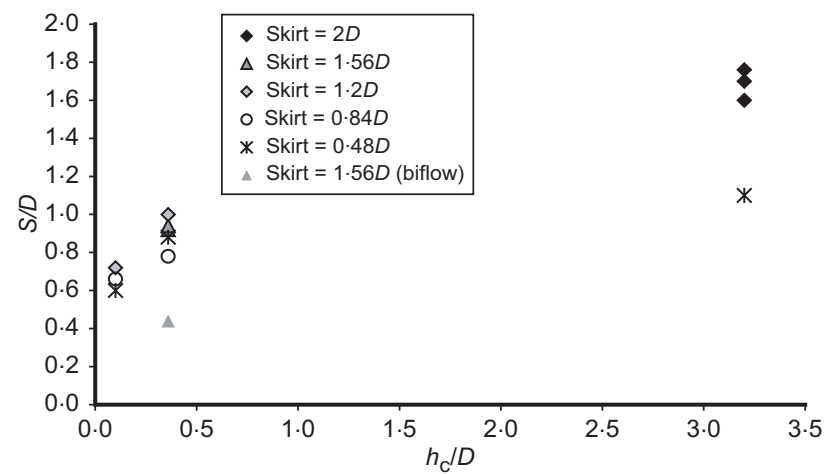

Figure 6. Results from Simons et al. (2009) tests on effect of skirt

of Simons et al. (2009) it was shown that the scour could extend to and undermine the full depth of the skirt. In those environments where appreciable wave action is present in addition to a fast current, the rate of scour is faster (Whitehouse, 2004) and, therefore, undermining of a skirt will potentially be quicker in storm conditions even if the overall scour depth is not necessarily greater owing to the limited duration of the storm.

\section{Scour extents and scour protection}

Management of scour can be achieved through placement of protection such as rock armour (riprap) with appropriate grading to resist the locally enhanced flow and turbulence around the structure; standard filter criteria should be met to resist loss of soil between the rock armour (CIRIA/CUR/ CETMEF, 2007). Whereas scour protection for monopile foundations may be assessed using existing results and methods (e.g. den Boon et al., 2004), a similar generic solution for GBFs is not available and the performance of the scour protection material needs to be quantified in laboratory hydraulic model tests. Zaaijer (2003, p. 8) concluded for GBFs and suction bucket foundations that scour is expected to be 'unacceptable, due to their high reliance on near-surface soil'. Therefore, in the scour management plan (Figure 1), bed preparation with additional scour protection is required in weak or granular soils.

The enhancements to the local flow field around the GBF can be calculated using computational fluid dynamics, although the performance of scour protection material is most clearly quantified for design conditions in laboratory hydraulic model tests. The extent of scour is an important parameter that dictates the coverage required by scour protection materials. Following installation of the structure, scour protection should be installed as soon as possible to minimise the potential for scour development. Monitoring of the performance of the scour protection will also be required (as advised for example by DNV, 2007) to confirm that the performance is within expected limits. Some examples are referred to by way of illustration. 
Following installation of the Malampaya GBF (McNulty et al., 2002: p. 8) on a bedding layer, described in Section 5 above, scour protection was added around the corners. Graded rock was placed by flexible fall pipe to a thickness of $1 \mathrm{~m}$ and to a distance of $15 \mathrm{~m}$ from the four corners of the structure. The base caisson was $112 \mathrm{~m} \times 83 \mathrm{~m} \times 16 \mathrm{~m}$ high with open ballast cells along two sides and four cylindrical shafts supporting the topside. Information on scour protection performance is not reported at the present time.

Scour protection around the F3 GBF $(70 \mathrm{~m} \times 80 \mathrm{~m} \times 16 \mathrm{~m})$ in $42 \mathrm{~m}$ of water was evaluated in hydraulic model tests (Bos et al., 2002). The scour extent was greatest at the corners, about $18 \mathrm{~m}$, by virtue of the disturbance to the flow field. Scour protection was designed using both gabion baskets of $0.3 \mathrm{~m}$ and $0.5 \mathrm{~m}$ extending $6 \mathrm{~m}$ from the wall of the GBF, with the thicker mattresses at the corners also overlain with Sarmac mattresses. The protection was laid on a $1 \mathrm{~m}$ gravel layer and fixed to the edges of the GBF with chains. Monitoring of the scour protection and scour was recommended as part of the SMP. The mattresses were found to be stable under the storm conditions experienced at site over the period 1992 (installation) to 1998. Scour that continued to form in the seabed around the edge of the protection was deemed 'acceptable'. From field monitoring, scour holes were already evident in the first annual survey and extended for at least $5 \mathrm{~m}$ outside the protection and later scour extended under the protection at one corner producing a slope of 1:2. Near another corner significant scour was prevented through placement of extra mattresses for pipeline protection and gravel dumping, for jack-up operations. Laboratory testing for scour protection design for the Adriatic LNG terminal GBF was reported by Chen et al. (2011). A series of tests explored the deformation of the rock berm protection under the action of design waves and currents and the results were used to optimise the layout for thickness and width.

Rance (1980) examined scour around cylindrical and square section structures. The extent of scour depth was summarised above and the extent of scour from the wall of the foundation was about $0 \cdot 5 D_{\mathrm{c}}$ for the cylindrical foundation and $1 D_{\mathrm{c}}$ for the square foundation, from the corner perpendicular to the one pointing into the direction of waves. The pattern of scour and deposition was similar to the work published by Sumer and Fredsøe (2001) under similar test conditions. Tests conducted by Rance for other conditions showed how the pattern of scour and deposition changed around the periphery of the caisson. If scour was considered detrimental to the foundation then scour protection would be required to cover the extent of the scoured area before it became well developed.

In the flat-topped girder caisson test with current only, for which the scour curve is plotted in Figure 2 (Table 2, Test 3), the scour extents were about $0 \cdot 5 D_{\mathrm{c}}$ from the foundation skirt (overall diameter $2 D_{\mathrm{c}}$ ). The extent of scour increased with current and wave action for the (similar) flat-topped structure (Figure 5(b)) and conical structure (Figure $5(\mathrm{a})$ ) to about $2 \cdot 5 D_{\mathrm{c}}$. The upstream slope of the scour hole is steepest, as in the case for scour around a monopile (Harris et al., 2010a). A $5 \mathrm{~m}\left(0 \cdot 26 D_{\mathrm{c}}\right)$ wide ring of $200 \mathrm{~kg}$ scour protection rock placed in a $1 \mathrm{~m}$ thick (double) layer on the sand bed with an overall diameter of $1 \cdot 5 D_{\mathrm{c}}$ was found to be effective in removing scour from the perimeter (Figure 5(c)). Scour development in the seabed around the rock occupied the same sort of extent as previously seen for the unprotected bed but with a much reduced depth $(0 \cdot 5-1 \mathrm{~m})$. The crest width of the armour rock retreated to $3 \mathrm{~m}$ from the foundation, and there was some undermining at the edges, generating a falling apron of rock one stone thick and slope of 1:4. The scour protection was found to be stable with a simulated reversal of flow, not reducing to less than $3 \mathrm{~m}$ width, although there was partial infilling of the previously scoured downstream area and new scour development around the armour to an overall depth of about $2 \mathrm{~m}$ in places with a scour slope of about 1:2. More extreme return period wave conditions would require a wider armour layer to compensate for the loss of rock that would be expected to occur.

From hydrographic surveys around the Christchurch Bay tower (Bishop, 1980) it was found the scour generated a shallow depression in the seabed with extents of deepest scour around $1-1 \cdot 5 D_{\mathrm{c}}$ and scour with an overall diameter of up to $5 D_{\mathrm{c}}$. It is considered that this larger diameter of scour pit is due to wake effects in the lee of the structure, which may not be fully resolved in laboratory tests. Scour protection was installed using a sand filter and coarse gravel as well as cement/sand bags and grout; in this case neither method proved successful as long-lasting remediation.

For the Thornton Bank case (Bolle et al., 2009), once scour had developed in waves and currents the extents around the exposed $17 \mathrm{~m}$ diameter (at seabed level) foundation were about $5 \mathrm{~m}$ around most of the GBF. Subsequent tests with current alone demonstrated that the width doubled to $10 \mathrm{~m}$ and up to $25 \mathrm{~m}$ downstream in the wake region, yielding an overall scour diameter of $2 \cdot 5 D_{\mathrm{c}}$, which is similar to the result for the conical structure in Figure 5(a). Their work demonstrated an important interplay of hydraulic and geotechnical effects. Future bed lowering has been accommodated through seabed dredging and placing granular backfill around the foundations and scour protection consisting of a widely graded armour $0.7 \mathrm{~m}$ thick overlying $0.6 \mathrm{~m}$ of a widely graded filter layer. Laboratory test results of the rock protection design confirmed stability and low edge scour with an overall protection diameter of $2 \cdot 5 D_{\mathrm{c}}$, and a greater edge scour for a reduced diameter of $2 D_{\mathrm{c}}$. Based on geotechnical considerations the minimum scour protection diameter was set at $2 \cdot 5 D_{\mathrm{c}}$ and increased, depending on location (geotechnical stability and 
water depth), to between $2 \cdot 9$ and $3 \cdot 9 D_{\mathrm{c}}$. The six foundations required a large overall dredging and backfill/armour effort and the second phase of the development is planned with multiple piled steel lattice foundations rather than GBF.

\section{Conclusions}

Gravity base foundations have been used for oil and gas and renewable projects as foundation solutions in deep and shallow water on different soils. The drive for renewable energy generation requires multiple foundations to be installed in the marine environment and GBFs are being considered as part of the solution. The soil properties at foundation level are required to evaluate the structural performance of GBFs from a geotechnical point of view and the potential hazard arising from seabed scour should be screened as part of the design process to ensure a stable foundation. Scour hazard is controlled by the sediment properties, the structure and the hydraulic action of waves and currents. Calculations can be carried out for single sites or as spatial mapping exercises for arrays of foundations.

The drive for offshore renewables may lead to a potentially large-scale implementation of GBFs. This means that the existing scour methods with their inherent limitations are going to be applied to a mass production design scenario. Integration of an SMP into the GBF design process, for which a framework has been suggested in the current paper (Figure 1), will provide a structured approach to scour hazard assessment, prediction of scour response, scour mitigation in the structural design, seabed preparation and placement of scour protection, and monitoring to evaluate performance against specified performance measures. The SMP should include the installation and operational phases of the structure's life, including decommissioning, and contain a procedure for remedial works in case these are identified as being required.

Good information on the soil properties at foundation level and on scour protection performance is required for a successful design. Scour protection will need to be installed in vigorous scour environments before installation or immediately postinstallation. This may require dredging of the seabed and placement of scour-resistant materials before installing the GBF.

Predictions of scour based on analysis of the flow fields and structure have used empirical approaches as well as more detailed methods. Results of published research show that a skirt, which may be required for GBF stability, does not necessarily prevent scour from developing and undermining the foundation. On sand beds the scour prediction methods based on the empirical formulae provide a first-order estimate of scour depth; for example, this will enable the risk of a skirt being undermined by scour to be evaluated. It should be possible to modify the shape or external details of the foundation to reduce the potential for scour, for instance by rounding off corners at scour critical areas.
Hydraulic tests in the laboratory provide valuable information on understanding scour and optimising scour protection for design. However, it is clearly the case that more research is required to provide the data for developing improved and more versatile prediction methods including the effect of skirts. In layered beds the situation is different, for example where sand overlies clay. This is because scour in the underlying layer will need to be predicted using analysis of soils data (e.g. Harris et al., 2010b) or direct erosion testing (e.g. Chen et al., 2011).

The time-varying current and wave fields need to be included in scour predictors as has been done for example for monopile structures (Harris et al., 2010a). Such an approach allows the role of time-scale for scour development to be evaluated to determine whether the scour is time limited or can develop fully. This will enable the risk of scour to be evaluated as part of the engineering assessment and SMP for the GBF so that effective mitigation measures can be put in place through scour protection placement or through scour monitoring and remedial works.

\section{Acknowledgements}

This paper is an extended version of an unpublished paper presented at the First IAHR European Division Congress, 4-6 May 2010, at Heriot Watt University. It also draws upon material brought together for presentations in 2008 by the first author to the Offshore Engineering Society (ICE) in London, the Telford Workshop at University of Dundee on Offshore Wind Farms and research funded by HR Wallingford. The authors' colleagues Mike Wallis and Chris Thomas are thanked for help in preparing some of the figures for this paper.

\section{REFERENCES}

Bishop JR (1980) Experience with scour at the Christchurch Bay tower. Proceedings of the One-day Society for Underwater Technology Seminar on Scour Prevention Techniques around Offshore Structures. Society for Underwater Technology, London, UK, pp. 11-22.

Bolle A, Haerens P, Trouw K, Smits J and Dewaele G (2009) Scour around gravity-based wind turbine foundations prototype measurements. In Coasts, Marine Structures and Breakwaters. Adapting to Change (Allsop W (ed.)). Thomas Telford, London, pp. 103-118.

Bos KJ, Chen Z, Verheij HJ, Onderwater M and Visser M (2002) Local scour and scour protection of F3 offshore GBS platform. In Proceedings of the 21st International Conference on Offshore Mechanics and Arctic Engineering.American Society of Mechanical Engineers, New York, NY, USA, paper 28127 (CD-ROM).

Brook Hart W, Cook R and Harris J (2010) Competitive concrete gravity base foundations for offshore wind farms. In Coasts, Marine Structures and Breakwaters. Adapting to Change (Allsop W (ed.)). Thomas Telford, London, UK, pp. 62-73. Burland JB, Penman ACM and Gallagher KA (1978) Behaviour of 
a gravity foundation under working and failure conditions. In Proceedings of the European Offshore Petroleum Conference and Exhibition, London, 24-27 October. Society of Petroleum Engineers, London, UK, paper EUR 13.

Byrne BW and Houlsby GT (2003) Foundations for offshore wind turbines. Philosophical Transactions of the Royal Society of London, A 361(1813): 2909-2930.

Chakrabarti SK and McBride M (2005) Station-keeping tests of moored caisson in strong current. Journal of Offshore Mechanics and Arctic Engineering 127(4): 315-322.

Chen Z, Hurdle D, Kram N, Lomónaco P and Cornett A (2011) Design and testing of scour protection for Adriatic LNG GBS. In Proceedings of the ASME 2011 30th International Conference on Ocean, Offshore and Arctic Engineering (OMAE2011), Rotterdam, the Netherlands, 19-24 June. American Society of Mechanical Engineers, New York, NY, USA, vol. 7, pp. 867-874.

CIRIA (Construction Industry Research and Information Association) (2002) C551: Manual on Scour at Bridges and other Hydraulic Structures. CIRIA, London, UK.

CIRIA (2010) C674: The Use of Concrete in Maritime Engineering - A Guide to Good Practice. CIRIA, London, UK.

CIRIA, CUR, CETMEF (2007) C683: The Rock Manual. The Use of Rock in Hydraulic Engineering, 2nd edn. CIRIA, London, UK.

Dahlberg R (1983) Observations of scour around offshore structure. Canadian Geotechnical Journal 20(4): 617-628.

Den Boon JH, Sutherland J, Whitehouse R et al. (2004) Scour behaviour and scour protection for monopile foundations of offshore windfarms. In Proceedings of the European Wind Energy Conference \& Exhibition, London, UK, 22-25 November. EWEA, Brussels, Belgium. See http://www. 2004ewec.info/ (accessed 10/11/2011).

DNV (Det Norske Veritas) (2007) Design of Offshore Wind Turbine Structures. Det Norske Veritas, Bærum, Norway, Offshore Standard Report DNV-OS-J101.

Fisher R and Cathie D (2002) Gravity based design for subsea structures.In Offshore Site Investigation and Geotechnics Diversity and Sustainability. Proceedings of the International Conference, London, UK, 26-28, November. The Society for Underwater Technology, London, UK.

Gerwick Jr BC (2000) Construction of Marine and Offshore Structures, 2nd edn. CRC Press, Boca Raton, FL, USA.

GL (Germanischer Lloyd) (2005) Guidelines for the Certification of Offshore Wind Turbines. Germanischer Lloyd, Hamburg, Germany.

Harris JM, Whitehouse RJS and Benson T (2010a) The time evolution of scour around offshore structures. Proceedings of the Institution of Civil Engineers - Maritime Engineering 163(1): 3-17.

Harris JM, Whitehouse RJS and Sutherland J (2010b). Scour assessment in complex marine soils - an evaluation through case examples. In Scour and Erosion-Proceedings of the Fifth International Conference on Scour and Erosion, San
Francisco, California, USA (Burns SE, Bhatia SK, Avila CMC and Hunt BE (eds)). American Society for Civil Engineers, Reston, VA, USA, Geotechnical Special Publication no. 210, pp. 450-459.

Hawkswood M and Allsop W (2009) Foundations to precast marine structures. In Coasts, Marine Structures and Breakwaters. Adapting to Change (Allsop W (ed.)). Thomas Telford, London, UK, pp. 86-102.

Hebsgaard M, Ennemark F, Spangenberg S, Fredsøe J and Gravesen H (1993) Scour model tests with bridge piers. PIANC Bulletin 82: 84-92.

Hoeg K (1991) Foundations for offshore structures. In Offshore Structures (Reddy DV and Arockiasamy M (eds)). Krieger Publishing, Malabar, FL, USA, vol. 2, chapter 11 (chapter written in 1982).

Hoffmans GJCM and Verheij HJ (1997) Scour Manual. Balkema, Rotterdam, the Netherlands.

Khalfin ISh (1983) Local scour around ice-resistant structures caused by wave and current effect. In Proceedings of the 7th International Conference on Port and Ocean Engineering under Arctic Conditions, Helsinki, Finland. Technical Research Centre of Finland, Espoo, Finland, VTT Symposium 28, vol. 2, pp. 992-1002.

Kjekstad O and Stub F (1978) Installation of the Elf TCP2 Condeep platform at the Frigg Field. In Proceedings of the European Offshore Petroleum Conference and Exhibition, London, 24-27 October. Society of Petroleum Engineers, London, UK, paper EUR 14.

Krogh L, Lyngs JH and Steenfelt JS (2011) Gravity base foundations for the Rødsand offshore wind farm, Denmark. In Proceedings of the 2nd International Symposium on Frontiers in Offshore Geotechnics, Perth, Australia, 8-10 November (Gourvenec S and White D (eds)). Balkema/Taylor \& Francis, Leiden, the Netherlands, pp. 587-592.

May RWP and Escarameia M (2002) Local scour around structures in tidal flows. In Proceedings of the 1st International Conference on Scour of Foundations, ICSF-1, Texas A\&M University, College Station, TX, USA, 17-20 November (Chen HC and Briaud JL (eds)). Texas Transportation Institute, College Station, TX, USA, pp. 320-336.

McNulty AJW, Grigsby A, Humpheson C et al. (2002) New developments in the design of concrete gravity substructures. In Proceedings of the 2002 Offshore Technology Conference, Houston, TX, USA, 6-9 May. OTC, Houston, TX, USA, paper OTC14189.

O'Riordan NJ and Clare DG (1990) Geotechnical considerations for the installation of gravity base structures. In Proceedings of the 22nd Offshore Technology Conference, Houston, TX, USA, OTC, Houston, TX, USA, paper OTC 6381, pp. 309-316.

Ottesen Hansen NE (2005) Experiences with simple and repetitive offshore foundations. In Proceedings of Copenhagen Offshore Wind 2005. National Wind 
Technology Center, National Renewable Energy Laboratory, US Department of Energy, Washington, DC, USA. See http://wind.nrel.gov/public/SeaCon/Proceedings/ Copenhagen.Offshore.Wind.2005/documents/papers/ Low_cost_foundations/ (accessed 10/11/2011).

Peire K, Nonneman H and Bosschem E (2009) Gravity base foundations for the Thornton Bank offshore wind farm. Terra et Aqua 115: 19-29.

Rance PJ (1980) The potential for scour around large objects. In Proceedings of the One-day Society for Underwater Technology Seminar on Scour Prevention Techniques Around Offshore Structures. Society for Underwater Technology, London, UK, pp. 41-53.

Rudolph D, Bijlsma AC, Bos KJ and Rietema K (2005) Scour around spud cans - analysis of field measurements. In Proceedings of the 15th (2005) International Offshore and Polar Engineering Conference, Seoul, Korea, 19-24 June (Chung JS, Hong SW, Koo J, Komai T and Koterayama W (eds)). ISOPE, Cupertino, CA, USA, pp. 289-295.

Simons RR, Weller J and Whitehouse RJS (2009) Scour development around truncated cylindrical structures. In Coastal Structures 2007, Proceedings of the 5th Coastal Structures International Conference, CSt07, Venice, Italy, 2-4 July (Franco L, Tomasicchio GR and Lamberti A (eds)). World Scientific, Singapore, pp. 1881-1891.

Sørensen SPH, Ibsen LB and Frigaard P (2011) Experimental evaluation of backfill in scour holes around offshore monopiles. In Frontiers in Offshore Geotechnics II: Proceedings of the 2nd International Symposium on Frontiers in Offshore Geotechnics, Perth, Australia, 8-10 November (Gourvenec S and White D (eds)). Balkema/Taylor \& Francis, Leiden, the Netherlands, pp. 617-622.

Stubbs SB (1975) Seabed foundation considerations for gravity structures. In Off-shore Structures - Proceedings of the Conference, London, 7-8 October 1974. ICE, London, UK, paper 7, pp. 64-74.

Sumer BM and Fredsøe J (2001) Wave scour around a large vertical circular cylinder. Journal of Waterway, Port, Coastal and Ocean Engineering 127(3): 125-134.

Sumer BM and Fredsøe J (2002) The Mechanics of Scour in the Marine Environment. World Scientific, Singapore.

Sutherland J, Brampton A and Whitehouse R (2006) Toe scour at seawalls: monitoring, prediction and mitigation. In Proceedings of the 41st Defra Flood \& Coastal Management Conference, The University of York, July. Department of the Environment, Food and Rural Affairs, London, UK, paper 3b.

The Concrete Centre (2010) Concrete Solutions for Wind Tower Foundations. MPA - The Concrete Centre, Camberley, UK.

Thomsen JH, Forsberg T and Bittner R (2007) Offshore wind turbine foundations - the COWI experience. In Proceedings of the 26th International Conference on Offshore Mechanics and Arctic Engineering. American Society of Mechanical Engineers, New York, NY, USA, paper 29567 (CD-ROM). Villalobos FAV (2009) Fundaciones para turbinas eólicas costa afuera. Revista Ingeniería de Construcción 24(1): 33-48 (in Spanish).

Whitehouse RJS (1998) Scour at Marine Structures. Thomas Telford, London, UK.

Whitehouse RJS (2004) Marine scour at large foundations. In Proceedings of the 2nd International Conference on Scour and Erosion, Singapore, November (Chiew YM, Lim SY and Cheng NS (eds)). Stallion Press, Singapore, pp. 455-463.

Whitehouse R (2006) Scour at coastal structures (invited lecture). In Proceedings of the 3rd International Conference on Scour and Erosion, 1-3, November. CURNET, Gouda, the Netherlands, pp. 52-59 (CD-ROM).

Whitehouse RJS, Lam C, Richardson S and Keel P (2010)

Evaluation of seabed stability and scour control around subsea gravity protection structures. In Proceedings of the 29th International Conference on Ocean, Offshore and Arctic Engineering, OMAE2010, Shanghai, China, 6-11 June. American Society of Mechanical Engineers, New York, NY, USA, paper 20999 (CD-ROM).

Whitehouse RJS, Harris JM, Sutherland J and Rees J (2011) The nature of scour development and scour protection at offshore windfarm foundations. Marine Pollution Bulletin 62(1): 73-88.

Yeow K and Cheng L (2004) Local scour around a vertical pile with a caisson foundation. In Asian and Pacific Coasts 2003 - Proceedings of the $2^{\text {nd }}$ International Conference (Goda Y, Kioka W and Nadaoka K (eds)). World Scientific, Singapore, pp. 118-119.

Zaaijer MB (2003) Comparison of monopile, tripod, suction bucket and gravity base design for a $6 \mathrm{MW}$ turbine. In Proceedings of the OWEMES 2003 European Seminar. Energy Research Centre of the Netherlands, Petten, the Netherlands. See http://www.ecn.nl/fileadmin/ecn/units/ wind/docs/dowec/2003-OWEMES-Support-structures.pdf (accessed 10/11/2011).

\section{WHAT DO YOU THINK?}

To discuss this paper, please email up to 500 words to the editor at journals@ice.org.uk. Your contribution will be forwarded to the author(s) for a reply and, if considered appropriate by the editorial panel, will be published as discussion in a future issue of the journal.

Proceedings journals rely entirely on contributions sent in by civil engineering professionals, academics and students. Papers should be 2000-5000 words long (briefing papers should be 1000-2000 words long), with adequate illustrations and references. You can submit your paper online via www.icevirtuallibrary.com/content/journals, where you will also find detailed author guidelines. 